\title{
PENGEMBANGAN MULTIMEDIA PEMBELAJARAN INTERAKTIF PADA MATA PELAJARAN IPS TERPADU
}

\author{
Abdul Rofiq \\ Program Studi Teknologi Pendidikan, Universitas Pendidikan Ganesha \\ abdul.rofiq@undiksha.ac.id
}

Luh Putu Putrini Mahadewi

Program Studi Teknologi Pendidikan, Universitas Pendidikan Ganesha lpp-mahadewi@undiksha.ac.id

Desak Putu Parmiti

Program Studi Teknologi Pendidikan, Universitas Pendidikan Ganesha dp-parmiti@undiksha.ac.id

\begin{abstract}
Abstrak
Penelitian ini bertujuan (1) untuk mendeskripsikan rancang bangun pengembangan multimedia pembelajaran interaktif pada mata pelajaran IPS, (2) untuk mengetahui validitas pengembangan multimedia pembelajaran interaktif pada mata pelajaran IPS, (3) untuk mengetahui efektifitas pengembangan multimedia pembelajaran interaktif pada mata pelajaran IPS. Penelitian ini merupakan penelitian pengembangan dengan menggunakan model ADDIE (analyze, design, development, implementasi, evaluation). Analisis data menggunakan analisis deskriptif kualitatif, kuantitatif dan statistik inferensial. Hasil penelitian ini adalah (1) deskripsi rancangan pengembangan, validitas hasil pengembangan multimedia dan efektivitas hasil pengembangan multimedia pembelajaran interaktif pada mata pelajaran IPS. Rancangan pengembangan media menghasilkan naskah multimedia pembelajaran interaktif mata pelajaran IPS. (2) Kualitas hasil pengembangan media menurut review ahli dan siswa yaitu: (a) ahli isi pembelajaran $90 \%$ berada pada kategori sangat baik; (b) ahli desain pembelajaran $86,67 \%$ berada pada kategori baik; (c) ahli media pembelajaran 92\% berada pada kategori sangat baik; d) uji coba perorangan $92,67 \%$ berada pada kategori sangat baik; (e) uji coba kelompok kecil 93,3\% berada pada kategori sangat baik; (f) dan uji coba lapangan $94,2 \%$ yang berada pada kategori sangat baik. (3) Efektivitas hasil pengembangan media multimedia pembelajaran interaktif pada mata pelajaran IPS menunjukkan signifikansi yang diperoleh adalah $t_{\text {hitung }}=12,72>t_{\text {tabel }}=$ 2,004. Ini berarti Multimedia Pembelajaran Interaktif pada mata pelajaran IPS efektif dalam meningkatkan hasil belajar siswa.
\end{abstract}

Kata Kunci: IPS, Multimedia, Pengembangan

\begin{abstract}
This study aims (1) to describe the design of the development of interactive learning multimedia on social studies subjects, (2) to determine the validity of the development of interactive learning multimedia on social studies subjects, (3) to determine the effectiveness of developing interactive learning multimedia on social studies subjects. This research is a development research using the ADDIE model (analyze, design, development, implementation, evaluation). Data analysis used descriptive qualitative, quantitative and inferential statistics. The results of this study are (1) description of the development design, the validity of the results of multimedia development and the effectiveness of the results of the development of interactive multimedia learning on social studies subjects. The design of media development produces interactive multimedia multimedia texts on social studies subjects. (2) The quality of the results of media development according to expert and student reviews, namely: (a) 90\% of learning content experts are in a very good category; (b) learning design experts $86.67 \%$ are in the good category; (c) learning media experts $92 \%$ are in a very good category; $d$ ) individual trials $92.67 \%$ are in the excellent category; (e) small group trials $93.3 \%$ are in the excellent category; $(f)$ and field trials of $94.2 \%$ which are in the very good category. (3) The effectiveness of the development of interactive learning multimedia media on social studies subjects shows the significance obtained is tcount $=12.72>t$ table $=2.004$. This means Interactive Learning Multimedia on social studies subjects is effective in improving student learning outcomes.
\end{abstract}

Keywords: Social Sciences, Multimedia, Development 


\section{PENDAHULUAN}

Perkembangan teknologi informasi sekarang ini sudah sangat pesat, artinya dalam proses pembelajaran antara pendidik (guru) maupun peserta didik sudah mulai memanfaatkan teknologi informasi yang semakin berkembang. Para guru sekarang ini dituntut untuk mampu mengintegrasikan teknologi dalam pembelajaran, salah satunya adalah dengan menggunakan media pembelajaran. Menurut Suartama (2012) "Media pembelajaran adalah segala sesuatu yang dapat digunakan untuk menyalurkan pesan dari pengirim ke penerima pesan sehinggga dapat merangsang pikiran, perasaan, perhatian dan minat siswa sedemikian rupa sehingga proses belajar terjadi". Media pembelajaran harus mampu menarik perhatian peserta didik dalam mengikuti proses pembelajaran dan dapat memotivasi siswa dalam mempelajari mata pelajaran yang didapatkan, tidak terkecuali mata pelajaran IPS Terpadu.

Namun dengan kemajuan teknologi belum mampu memaksimalkan proses belajar mengajar dikelas, maka dari itu di perlukan sebuah metode pembelajaran yang sesuai dan juga mampu memanfaatkan media yang tersedia. Belajar merupakan sebuah perubahan yang relatif permanen dalam perilaku atau potensi prilaku sebagai hasil dari pengalaman atau latihan yang diperkuat.

Fakta yang terdapat di tempat observasi pada tanggal 04 April 2016 yaitu di SMP Negeri 1 Sukasada sudah cukup jelas terlihat bahwa kemajuan dalam dukungan fasilitas pendukung telah cukup memadai sesuai dengan kebutuhan proses pembelajaran.

Fasilitas yang dimaksud seperti TV, LCD Proyektor, Komputer, VCD dan fasilitas lain yang dapat mendukung proses pembelajaran. Akan tetapi, fungsi serta pemanfaatan dari fasilitas tersebut tidak dapat dimaksimalkan oleh guru-guru di sekolah tersebut. Hasil observasi di lapangan juga menunjukan bahwa dalam pembelajaran Ilmu Pengetahuan Sosial di kelas proses belajar-mengajar masih didominasi oleh guru.

Hal ini dilakukan oleh guru karena guru mengajar mengejar target kurikulum untuk menghabiskan meteri pembelajaran atau bahan ajar dalam kurun waktu tertentu. Guru juga lebih menekankan pada siswa untuk menghapal konsep-konsep, yang nantinya bias digunakan oleh siswa dalam menjawab soal ulangan harian, ulangan umum ataupun ujian akhir nasional (UAN) tanpa melihat secara nyata manfaat materi yang diajarkan dalam kehidupan sehari-hari. Maka dari itu yang menjadi pedoman dan rasional penulisan, untuk mengangkat tema "pengembangan" terutama dalam hal media pembelajaran dan berdasarkan tinjauan di lokasi dan wawancara dengan guru Ilmu Pengetahuan Sosial Kelas VII SMP Negeri 1 Sukasada.

Kurang maksimalnya pemanfaatan fasilitas pembelajaran di SMP Negeri 1 Sukasada dikarenakan terbatasnya pengetahuan guru tentang media pembelajaran dan cara-cara inovatif dan kreatif sehingga pembelajaran dikelas tidak berlangsung optimal. Ini dapat dibuktikan dengan hasil belajar ulangan tengah semester (UTS) pada mata pelajaran Ilmu Pengetahuan Sosial masih dibawah standar kreteria ketuntasan minimal (KKM) 75 ditemukan rata-rata murni (sebelum diadakan remedial) pada pelajaran Ilmu Pengetahuan Sosial khususnya Kelas VII masih belum memuaskan yaitu 60. Setelah diadakan remedial mendapatkan hasil 70 yang belum memenuhi standar.

Sehingga dalam penelitian ini diharapkan mampu memberikan kontribusi positif terutama dalam hal penyediaan media pembelajaran yang berimplikasi pada hasil belajar Ilmu Pengetahuan Sosial Kelas VII di SMP Negeri 1 Sukasada. Sebagai salah satu komponen penting dalam meningkatkan kualitas pendidikan kegiatan belajar mengajar (KBM) perlu diubah atau direvisi agar mampu meningkatkan prestasi belajar, kemampuan pemecahan masalah, penalaran siswa menggunakan Multimedia Pembelajaran.

Berdasarkan paparan tersebut, maka dalam penelitian ini dicoba untuk melakukan penelitian pengembangan dengan judul "Pengembangan Multimedia yang Berorientasi pada Pembelajaran Kontekstual untuk Meningkatkan Hasil Belajar Siswa pada Mata Pelajaran IPS Kelas VII Tahun Pelajaran 2018/2019 di SMP Negeri 1 Sukasada".

Berdasarkan permasalahan diatas tujuan yang diharapkan dari penelitian pengembangan ini adalah untuk (1) Mendeskripsikan rancang bangun pengembangan Multimedia yang berorientasi pada pembelajaran Kontekstual menggunakan model pengembangan ADDIE pada mata pelajaran IPS Kelas VII Semester Genap Tahun pelajaran 2018/2019 di SMP Negeri 1 Sukasada. (2) Mengetahui validitas hasil pengembangan Multimedia Pembelajaran IPS menurut uji ahli isi, uji ahli media pembelajaran, uji ahli desain pembelajaran, uji coba kelompok dan uji coba lapangan. (3) Mengetahui efektifitas Multimedia Pembelajaran dalam pembelajaran IPS Kelas VII semester genap tahun pelajaran 2018/2019 di SMP Negeri 1 Sukasada.

\section{METODE}

Dalam penelitian ini peneliti menggunakan model pengembangan model ADDIE (Analysis, Design, Development, Implementation, and Evaluations). Model ADDIE merupakan salah satu model desain pembelajaran sistematik (Tegeh, dkk 2014). Pemilihan model ini didasari atas pertimbangan secara sistematis dan berpijak pada landasan teoritis suatu pembelajaran. Model ini tersusun secara terprogram dengan urutanurutan kegiatan yang sistematis dalam upaya pemecahan masalah belajar yang berkaitan dengan suatu sumber 
belajar yang disesuaikan dengan kebutuhan dan karakteristik pebelajar di lapangan yang dalam hal ini adalah siswa SMP Negeri 1 Sukasada.

Pada penelitian ini menggunakan tiga metode pengumpulan data, yaitu metode wawancara, metode pencatatan dokumen, metode kuesioner dan metode tes. Dalam penelitian pengembangan ini digunakan tiga teknik analisis data, yaitu teknik analisis deskriptif kuantitatif, teknik analisis deskriptif kualitatif dan Metode Analisis Statistik Inferensial/ Induktif.

(1) Analisis deskriptif kuantitatif digunakan untuk mengolah data yang diperoleh melalui angket dalam bentuk skor. Rumus yang digunakan untuk menghitung menurut Tegeh, dkk (2014:82) dari masing-masing subjek sebagai berikut.

$$
\text { Persentase }=\frac{\Sigma x}{S M I} x 100 \%
$$

Keterangan :

$\sum \mathrm{x} \quad=$ jumlah skor

SMI $=$ Skor Maksimal Ideal

Selanjutnya untuk menghitung presentase keseluruhan subjek digunakan rumus :

Presentase $=\mathbf{F}: \mathbf{N}$

(Tegeh, dkk, 2014)

Keterangan :

(Tegeh, dkk, 2014)

$\mathrm{F}=$ jumlah presentase keseluruuhan

subyek

$\mathrm{N}$ = banyak subjek

Untuk dapat memebrikan makna dan pengambilan keputusan digunakan ketetapan konversi tingkkat pencaapaian dengan skala lima yaitu sebagai berikut.

Tabel 1. Konversi Tingkat Pencapaian dengan Skala 5

\begin{tabular}{cll}
\hline Tingkat Pencapaian & \multicolumn{1}{c}{ Kualifikasi } & \multicolumn{1}{c}{ Keterangan } \\
\hline $90 \%-100 \%$ & Sangat baik & Tidak perlu direvisi \\
$75 \%-89 \%$ & Baik & Direvisi Seperlunya \\
$65 \%-74 \%$ & Cukup & Cukup Banyak Direvisi \\
$55 \%-64 \%$ & Kurang & Banyak Direvisi \\
$0-54 \%$ & Sangat Kurang & Direvisi Total \\
\hline
\end{tabular}

(2) Analisis deskriptif kuantitaif. Data dalam penelitian kualitatif bersifat deskriptif bukan angka. Data dapat berupa gejala-gejala, kejadian dan peristiwa yang kemudian dianalisis dalam bentuk kategori-kategori.

(3) Analisis Statistik inferensial digunakan untuk mengetahui tingkat keefektifan produk terhadap hasil belajar IPS pada siswa Kelas VII SMP Negeri 1 Sukasada, sebelum dan sesudah menggunakan produk pengembangan Multimedia Pembelajaran dalam mata pelajaran IPS. Data uji coba kelompok sasaran dikumpulkan dengan menggunakan pre-test dan post-test terhadap materi pokok yang diuji cobakan.

Hasil pre-test dan post-test kemudian dianalisis menggunakan uji t untuk mengetahui perbedaan antara hasil pre-test dan post-test. Pengujian hipotesis digunakan untuk uji t berkorelasi dengan bantuan program computer SPSS dan/atau penghitungan hasil dengan penghitungan manual. Sebelum melakukan uji hipotesis (uji t berkorelasi) dilakukan uji prasyarat (normalitas dan homogenitas). Rumus untuk menghitung uji prasyarat dan uji hipotesis (uji t berkorelasi) adalah sebagai berikut.

a) Uji normalitas dilakukan untuk mengetahui apakah sebaran skor pada setiap variable berdistribusi normal atau tidak, untuk itu dapat digunakan rumus Chi-Kuadrat.

b) Uji homogenitas ini dilakukan untuk mencari tingkat kehomogenan secara dua pihak yang diambi dari kelompok-kelompok terpisah dari satu populasi yaitu kelompok kontrol dan kelompok eksperimen.

c) Uji Hipotesis (Uji t berkolerasi)

Teknik analisis yang digunakan untuk pengujian hipotesis adalah dengan teknik analisis uji t berkorelasi atau dependen. Dasar penggunaan teknik uji t berkorelasi ini adalah menggunakan dua perlakuan yang berbeda 
terhadap satu sampel. Pada penelitian ini akan menguji perbedaan hasil belajar IPS sebelum dan sesudah menggunakan produk Multimedia Pembelajaran terhadap satu kelompok.

Hasil uji coba dibandingkan $\mathrm{t}_{\text {tabel }}$ dengan taraf signifikan $0,05(5 \%)$ untuk mengetahui apakah ada perbedaan antara sebelum dan sesudah menggunakan produk Multimedia Pembelajaran.

\section{Hasil dan Pembahasan}

Rancang bangun pengembangan media Multimedia Pembelajaran IPS ini menggunakan model pengembangan ADDIE, adapun tahapannya adalah sebagai berikut. (a) Analisis kebutuhan. Berdasarkan hasil analisis kebutuhan sebagian besar siswa menyatakan pembelajaran yang berlangsung di kelas membosankan karena guru mengajar hanya menggunakan metode ceramah saja dan sumber belajar yang ada contoh-contoh yang diberikan belum sesuai dengan lingkungan siswa. Sementara jika dilihat dari fasilitas pembelajaran yang dimiliki oleh SMP Negeri 1 Sukasada terbilang lengkap, karena sudah tersedia LCD, Layar Proyektor, Komputer, dan lain-lain namun guru-guru sangat jarang memanfaatkan fasilitas yang tersedia. Oleh karena itu dipandang perlu untuk mengembangan sebuah media pembelajaran yang berbantuan komputer seperti media Multimedia Pembelajaran untuk diterapkan di SMP Negeri 1 Sukasada. (b) Merancang storyboard dan flowchart. (c) Melakukan produksi multimedia pembelajaran. (d) Selanjutnya, pada tahap implementasi, hasil pengembangan media Multimedia Pembelajaran di terapkan pada siswa sasaran. (e) Tahap terakhir adalah tahap evaluasi, media Multimedia Pembelajaran ini melalui dua tahap evaluasi yaitu yang pertama tahap validasi yang dilakukan oleh ahli isi mata pelajaran, ahli desain pembelajaran, ahli media pembelajaran dan uji coba siswa. Tahap yang kedua yaitu tahap uji efektivitas yang dilakukan oleh siswa sasaran media.

Validitas hasil pengembangan media Multimedia Pembelajaran ini akan disajikan mulai dari uji ahli isi mata pelajaran, uji ahli desain pembelajaran, uji ahli media pembelajaran, uji coba perorangan, uji coba kelompok kecil dan uji coba lapangan.

Uji Ahli Isi Mata Pelajaran, Produk ini dinilai oleh seorang ahli isi mata pelajaran sekaligus sebagai guru mata Kelas VII SMP Negeri 1 Sukasada atas nama Desak Nyoman Harum Saptyarani, S.Pd. Instrumen yang digunakan untuk uji coba ahli isi mata pelajaran ini adalah angket/kuisioner. Metode yang digunakan untuk mengumpulkan data adalah metode kuisioner. Berdasarkan hasil penilaian dari ahli isi mata pelajaran, setelah dikonversikan dengan tabel konversi, persentase tingkat pencapaiannya sebesar $88,89 \%$ berada pada kualifikasi baik, sehingga dari segi isi/substansi materi yang disajikan dalam media Multimedia Pembelajaran ini tidak perlu direvisi.

Uji Ahli Desain Pembelajaran, Produk media Multimedia Pembelajaran ini diujicobakan kepada seorang ahli desain pembelajaran atas nama Dr. I Made Tegeh, S.Pd., M.Pd. Berdasarkan hasil penilaian dari ahli desain pembelajaran, setelah dikonversikan dengan tabel konversi, persentase tingkat pencapaiannya sebesar 79,13\% berada pada kualifikasi baik, sehingga media Multimedia Pembelajaran ini perlu direvisi seperlunya.

Uji Ahli Media Pembelajaran. Media pembelajaran di uji cobakan kepada seorang ahli media pembelajaran atas nama Dr. I Gde Wawan Sudatha, S.Pd., S.T., M.Pd. Berdasarkan hasil penilaian dari ahli media pembelajaran, setelah dikonversikan dengan tabel konversi, persentase tingkat pencapaiannya sebesar 86,67\% berada pada kualifikasi baik, sehingga media Multimedia Pembelajaran ini tidak perlu direvisi.

Uji Coba Perorangan, Sebagai subjek dari uji coba perorangan ini adalah siswa Kelas VIII sebanyak tiga orang. Berdasarkan hasil penilaian dari uji coba perorangan, setelah dikonversikan dengan tabel konversi, persentase tingkat pencapaiannya sebesar $88 \%$ berada pada kualifikasi baik, sehingga media Multimedia Pembelajaran Berbasis ini tidak perlu direvisi.

Uji Coba Kelompok Kecil. Dalam uji coba kelompok kecil, subjek coba dalam penelitian ini adalah siswa Kelas VIII sebanyak 12 (dua belas orang). Berdasarkan hasil penilaian dari uji coba kelompok kecil, setelah dikonversikan dengan tabel konversi, persentase tingkat pencapaiannya sebesar $86 \%$ berada pada kualifikasi baik, sehingga media Multimedia Pembelajaran ini tidak perlu direvisi.

Uji Coba Lapangan. Sebagai subjek coba dalam uji coba lapangan yaitu kepada siswa Kelas VIII dengan jumlah siswa sebanyak 30 orang siswa. Berdasarkan hasil penilaian dari uji coba lapangan, setelah dikonversikan dengan tabel konversi, persentase tingkat pencapaiannya sebesar $86,87 \%$ berada pada kualifikasi baik, sehingga media Multimedia Pembelajaran ini tidak perlu direvisi.

Dalam pengembangan media Multimedia Pembelajaran ini melalui enam tahapan yaitu uji ahli isi mata pelajaran, uji ahli desain pembelajaran, uji ahli media pembelajaran, uji coba perorangan, uji coba kelompok kecil, dan uji coba lapangan. Dalam ke enam tahapan tersebut tidak ada yang perlu banyak direvisi namun hanya ada beberapa tambahan dan masukan dari para ahli dan subjek uji coba.

Sebelum menguji efektivitas produk pengembangan media Multimedia Pembelajaran pada pembelajaran IPS, peneliti melakukan pretest terhadap 28 siswa di Kelas VII SMP Negeri 1 Sukasada. Selanjutnya diteruskan melakukan posttest terhadap 28 siswa. Adapun hasil pretest dan posttest disajikan dalam tabel berikut 
Tabel 2. Hasil Pretest dan Posttest pada Mata Pelajaran IPS

\begin{tabular}{cccc}
\hline No & Banyak Responden & Pretest & Posttest \\
\hline & 28 siswa & 1430 & 2425 \\
& Rata-rata & 51,25 & 88,39 \\
\hline
\end{tabular}

Dari hasil analisis pretest dan posttest 28 siswa didapatkan rata-rata pretest sebesar 51,25 dan nilai ratarata posttest sebesar 88,39. Berdasarkan nilai pretest dan posttest 28 siswa tersebut, maka dilakukan uji-t untuk sampel berkorelasi secara manual. Sebelum melakukan uji hipotesis (uji-t), perlu dilakukan uji prasyarat analisis data yang meliputi uji normalitas dan uji homogenitas. Adapun pemaparannya sebagai berikut. (1) Uji Normalitas. Uji normalitas data dilakukan untuk menyajikan bahwa sampel benar-benar berasal dari populasi yang berdistribusi normal. Uji normalitas data dilakukan terhadap data 28 siswa dari hasil belajar IPS siswa sebelum dan sesudah menggunakan media Multimedia Pembelajaran. Uji normalitas data dilakukan dengan teknik Liliefors. Berdasarkan hasil analisis uji normalitas data yang dilakukan, dapat disajikan pada tabel berikut.

Tabel 3. Hasil Uji Normalitas Pretest dan Posttest

\begin{tabular}{ccccc}
\hline No & Kelompok Data Hasil Belajar & $\chi^{\mathbf{2}}$ hitung & $\chi^{\mathbf{2}}$ tabel & Status \\
\hline Pretest & 5,710 & 7,815 & Normal \\
Postest & 5,638 & 7,815 & Normal \\
\hline
\end{tabular}

Berdasarkan Tabel 3 terlihat bahwa hasil perhitungan dengan menggunakan rumus chi-kuadrat, diperoleh $\chi^{2}$ hitung $<\chi^{2}$ tabel dengan taraf signifikansi 5\%. Dengan demikian semua data skor hasil belajar IPS berdistribusi normal. (2) Uji Homogenitas. Homogenitas data dianalisis dengan uji-F, dengan kriteria data homogen jika $\mathrm{F}^{2}$ hitung $\leq \mathrm{F}^{2}$ tabel, dan data tidak homogen jika $\mathrm{F}^{2}$ hitung $\geq \mathrm{F}^{2}$ tabel. Hasil homogenitas disajikan dalam tabel berikut.

Tabel 4. Hasil Uji Homogenitas Pretest dan Posttest

\begin{tabular}{cccc}
\hline Data & Fhitung & Ftabel & Keterangan \\
\hline $\begin{array}{c}\text { Pretest } \\
\text { Postest }\end{array}$ & 2,742 & 2,777 & Homogen \\
\hline
\end{tabular}

Berdasarkan hasil pengujian diperoleh Fhitung $=2,742$ sedangkan Ftabel= 2, 777 dengan taraf signifikansi 5\%. Jadi dapat disimpulkan Fhitung $\leq$ Ftabel sehingga kedua data tersebut memiliki varians yang homogen. (3) Uji Hipotesis. Pengujian hipotesis penelitian dilakukan dengan analisis uji-t sampel berkorelasi. Semua pengujian hipotesis dilakukan pada taraf signifikansi 5\%. Kriteria pengujian adalah apabila hasil perhitungan diperoleh nilai thitung > ttabel maka H0 ditolak dan H1 diterima. Hasil uji-t disajikan pada tabel sebagai berikut.

Tabe 5. Rangkuman Hasil Uji-t

\begin{tabular}{lcccccc}
\hline Data & N & $\begin{array}{l}\text { Rata- } \\
\text { rata }\end{array}$ & 2(Varians) & Db(n1+n2-2) & Thit & Ttab \\
\hline Pretest & & $: 51,25$ & 167,824 & 54 & 12,72 & 2,004 \\
Postest & 8 & 88,39 & 61,210 & 54 & \\
\hline
\end{tabular}

Berdasarkan hasil uji-t diperoleh thitung $=12,72$ dan ttabel $=2,004$ untuk $\mathrm{db}=54$ dari taraf signifikansi 5\%. Hal ini berarti thitung > ttabel, sehingga H0 ditolak dan H1diterima. Berdasarkan kriteria pengujian, H0 ditolak dan H1 diterima yang artinya media Multimedia Pembelajaran IPS tentang Penerapan Pesawat Sederhana dalam Kehidupan Sehari-hari efektif dalam meningkatkan hasil belajar siswa Kelas VII pada mata pelajaran IPS di SMP Negeri 1 Sukasada tahun pelajaran 2018/2019.

Rancang bangun pengembangan multimedia pembelajaran IPS menggunakan model ADDIE. Rancangan pengembangan media Multimedia Pembelajaran ini berupa storyboad dan flowchart. Storyboad dan flowchart dihasilkan pada tahap desain pada model pengembangan ADDIE (Analysis, Design, Development, 
Implementation and Evaluation) bertujuan untuk mempermudah dalam mengatur tata letak. yakni penerapan kegiatan ekonomi dalam kehidupan sehari-hari pada mata pelajaran IPS Kelas VII Sekolah Menengah Pertama. Penayangan Multimedia Pembelajaran dilengkapi dengan contoh penerapan kegiatan ekonomi dalam kehidupan sehari-hari yang lebih kontekstual sehingga siswa belajar menggunakan multimedia dan mengetahui contoh penerapan masing-masing jenis daripada kegiatan ekonomi. Multimedia ini dilengkapi dengan pemberian kesimpulan dan evaluasi untuk mengetahui pemahaman siswa terhadap materi pembelajaran yang telah ditayangkan pada Multimedia. Multimedia Pembelajaran yang dirancang harus berperan untuk menunjang proses pembelajaran. Hal ini didukung dengan teori tentang peranan Multimedia Pembelajaran, diantaranya (1) dapat menarik perhatian siswa sehingga dapat menumbuhkan motivasi belajar, (2) memperjelas makna bahan pengajaran sehingga mudah dipahami siswa, (3) metode pengajaran lebih bervariasi, dan (4) siswa lebih banyak melakukan kegiatan belajar (Mahadewi, 2012). Model pengembangan ADDIE yang digunakan dalam mengembangkan media Multimedia Pembelajaran dinyatakan berhasil karena tahapan-tahapan dari model ADDIE yang sistematis sehingga dapat menghasilkan media Multimedia Pembelajaran yang menarik, sesuai dengan karakteristik pengguna, dan efektif dalam meningkatkan hasil belajar siswa Kelas VII pada mata pelajaran IPS. Hal ini sejalan dengan pendapat Tegeh, dkk (2014 : 41) yang menyatakan bahwa model ADDIE disusun secara terprogram dengan urutan-urutan kegiatan yang sistematis dalam upaya pemecahan masalah belajar yang berkaitan dengan sumber belajar yang sesuai dengan kebutuhan dan karakteristik pebelajar. Hal ini sejalan dengan penelitian yang dilakukan (Laksana \& Widiastika, 2017) multimedia dapat mengembangkan siswa untuk dapat memecahkan masalah, berpikir global bertindak lokal, dan membawa ilmu pengetahuan untuk melayani hidup. (Andrian et al 2017) juga menyatakan multimedia dapat meningkatkan hasil belajar serta sebagai Upaya pelestarian dapat dilakukan dengan memperkenalkan nilai-nilai kepada siswa, terutama bagi siswa sekolah dasar sebagai pondasi awal dalam membentuk karakter siswa. Mengenalkan pada pembelajaran di sekolah dasar dapat dilakukan dengan cara mengintegrasikan konten dalam bentuk multimedia untuk memudahkan dan menarik perhatian siswa dalam belajar.Validitas hasil pebgembangan media Multimedia Pembelajaran IPS ini ditentukan berdasarkan hasil evaluasi oleh (1) ahli isi pembelajaran, (2) ahli desain pembelajaran, (3) ahli media pembelajaran, (4) siswa melalui uji coba perorangan, uji coba kelompok kecil, dan uji coba lapangan.

Berdasarkan hasil evaluasi dari ahli isi mata pelajaran IPS, diketahui bahwa media Multimedia Pembelajaran berada pada kualifikasi baik yaitu $88,89 \%$. Jika direview ulang dari aspek ahli isi mata pelajaran IPS, rancangan media Multimedia Pembelajaran memperoleh kualifikasi baik karena proses penyusunannya sudah berdasarkan sumber-sumber yang relevan, baik itu berupa buku, maupun sumber dari internet. Penentuan materi juga tidak terlepas dari silabus dan RPP yang digunakan, dan juga telah melalui pertimbangan dari ahli pada bidang studi yang bersangkutan. Selain itu ahli isi pembelajaran juga mengatakan bahwa melalui Multimedia Pembelajaran ini dapat menjelaskan konsep-konsep yang rumit. Hal ini sejalan dengan pendapat Arsyad (2011) yang mengatakan Multimedia Pembelajaran dapat menyajikan informasi, memaparkan proses, menjelaskan konsep-konsep yang rumit, mengajarkan keterampilan, menyingkat atau memeperpanjang waktu, dan mempengaruhi sikap. Dilihat dari komentar dan saran yang diberikan oleh ahli isi mata pelajaran IPS menunjukkan tidak perlu adanya revisi terhadap isi dari media. Dari segi kejelasan kompetensi dasar, kejelasan tujuan pembelajaran, kejelasan tujuan dengan materi, kejelasan penyajian materi, petunjuk belajar, kelengkapan materi, kejelasan bahasa yang digunakan, kesesuaian contoh yang digunakan, kecukupan evaluasi, dan kesesuaian evaluasi dengan tujuan. Namun demikian, ahli isi pembelajaran memberikan saran dan komentar pada bagian bentuk soal pada evaluasi yaitu agar diperbaiki sesuai dengan penulisan bentuk soal yang baik dan benar.

Berdasarkan review oleh ahli desain pembelajaran validitas hasil pengembangan media Multimedia Pembelajaran ini memperoleh persentase sebesar 79,13\% yang berada pada kategori baik yang artinnya media Multimedia pembelajarn ini direvisi seperlunya. Dilihat dari komentar dan saran yang diberikan oleh ahli desain pembelajaran menunjukkan tidak perlu adanya revisi dari segi ketepatan penggunaan desain/rancangan penyajian materi, kejelasan pembahasan, contoh, simulasi, latihan, kejelasan konten yang disediakan, kesesuaian desain dalam memotivasi minat belajar, kesesuaian tampilan desain Multimedia, animasi, suara, gambar, dan musik, dengan materi yang disajikan, kejelasan teks yang digunakan, kesesuaian durasi dengan karakteristik siswa, kejelasan soal evaluasi. Hal ini sejalan dengan pendapat Carl and Rosalind (2011) dalam Yaumi (2013:11) mengatakan bahwa desain pembelajaran sebagai suatu proses adalah pengembangan sistematik tentang spesifikasi pembelajaran dengan menggunakan teori belajar dan pembelajaran untuk mencapai kualitas pembelajaran. Dari definisi tersebut desain pembelajaran dipandang sebagai keseluruhan proses analisis terhadap kebutuhan belajar, tujuan, dan pengembangan sistem penyampaian untuk memenuhi kebutuhan tersebut. Proses tersebut mencangkup pengembangan materi dan aktivitas pembelajaran, uji lapangan, dan evaluasi terhadap seluruh pembelajaran dan aktivitas-aktivitas peserta didik. Namun demi kesempurnaan media Multimedia Pembelajaran ini ahli desain pembelajaran memberikan beberapa masukan, saran dan revisi yaitu pada bagian kesimpulan agar ditambahkan contoh penerapan pesawat sederhana pada jenis katrol. 
Validitas hasil pengembangan media Multimedia Pembelajaran berdasarkan review oleh ahli media pembelajaran memperoleh persentase sebesar $86,67 \%$ yang berada pada kategori baik yang artinnya media Multimedia pembelajaran ini tidak perlu direvisi. Dilihat dari komentar dan saran yang diberikan oleh ahli media pembelajaran menunjukkan tidak perlu adanya revisi dari segi kesesuaian media dengan peserta didik, keteraturan musik yang digunakan, ukuran, jenis, dan warna huruf pada Multimedia proposional, kemenarikan tampilan media, media pembelajaran dapat diinstalasi/ dijalankan di berbagai hardware yang ada, Kemenarikan desain cover CD. Namun demikian, ahli media pembelajaran memberikan saran dan komentar pada Gambar orang menari dihilangkan, penanaman kelas diganti menjadi kelas VII, pada saat menekan tombol keluar perlu ada konfirmasi, gambar harus sesuai dan terlihat jelas. Hal ini sejalan dengan kajian pustaka yaitu pemaknaan terhadap bahan pengajaran yang bersifat abstrak/kompleks perlu dibarengi dengan deskripsi yang jelas sehingga sesuatu yang abstrak/kompleks tersebut dapat ditelaah secara lebih konkret/sederhana oleh siswa. (Mahadewi, dkk, 2012).

Media Multimedia Pembelajaran yang dikembangkan telah melewati hasil review dari para ahli, yaitu ahli isi pembelajaran, ahli desain pembelajaran, dan ahli media pembelajaran, kemudian produk diujicobakan pada siswa Kelas VII di SMP Negeri 1 Sukasada. Pada aspek uji coba perorangan, kualitas produk pengembangan mencapai tingkat persentase $88 \%$ berada pada kualifikasi baik. Pada aspek uji coba kelompok kecil, kualitas produk mencapai tingkat persentase $86 \%$ berada pada kualifikasi baik. Pada uji coba lapangan, kualitas produk mencapai tingkat $86,87 \%$ berada pada kualifikasi baik. Adapun alasannya Multimedia Pembelajaran ini berada pada kualifikasi baik sesuai hasil dari uji coba perorangan, kelompok kecil, dan lapangan karena dilihat dari aspek kemenarikan media, kemudahan memahami materi yang disajikan, serta kejelasan materi yang diberikan. Semua aspek tersebut sudah sesuai dengan tayangan Multimedia sehingga tayangan Multimedia dapat memotivasi siswa dalam belajar sehingga konten Multimedia dapat dengan mudah dipahami oleh siswa. Hal ini sejalan dengan kajian pustaka yakni pada peranan media Multimedia Pembelajaran (1) dapat menarik perhatian siswa sehingga dapat menumbuhkan motivasi belajar dan (2) memperjelas makna bahan pengajaran sehingga mudah dipahami siswa. (Mahadewi, dkk, 2012). Selain itu Menurut Midun (2009) dalam Asyhar (2012) Media pembelajaran dapat menambah kemenarikan tampilan materi sehingga meningkatkan motivasi dan minat serta mengambil perhatian peserta didik untuk fokus mengikuti materi yang disajikan, sehingga diharapkan efektifitas belajar akan meningkat pula. Arsyad (2011) juga berpendapat bahwa Film dan Multimedia dapat ditunjukkan kepada kelompok besar atau kelompok kecil, kelompok yang heterogen, maupun perorangan.

Rata-rata validitas hasil pengembangan media Multimedia Pembelajaran ini berada pada kualifikasi sangat baik, jadi media Multimedia Pembelajaran ini tidak perlu direvisi, dan dapat dilanjutkan pada tahap uji efektivitas produk.

Hasil uji efektifitas menunjukan rata-rata hasil posttest siswa lebih tinggi dibandingkan dengan rata-rata hasil pretest. Peningkatan rata-rata nilai siswa ini juga dapat dilihat berdasarkan jawaban-jawaban siswa saat menjawab tes. Sebagian besar jawaban siswa yang salah saat pretest, benar saat posttes. Hal ini disebabkan karena media Multimedia Pembelajaran ini digunakan saat proses pembelajaran, sehingga siswa lebih antusias dan tertarik untuk belajar.

Dilihat dari konversi hasil belajar di Kelas VII SMP Negeri 1 Sukasada, nilai rata-rata posttest peserta didik 88,39 berada pada kualifikasi Baik, dan berada di atas nilai KKM mata pelajaran IPS sebesar 69. Melihat nilai rerata atau mean posttest yang lebih besar dari nilai rerata atau mean pretest, dapat dikatakan bahwa media Multimedia Pembelajaran pada mata pelajaran IPS dapat meningkatkan hasil belajar IPS siswa Kelas VII SMP Negeri 1 Sukasada semester genap.

Menggunakan media Multimedia Pembelajaran dapat meningkatkan hasil belajar siswa disebabkan karena Multimedia Pembelajaran memberikan kemudahan kepada guru dan siswa untuk memahami materi yang diberikan, dibandingkan dengan hanya menggunakan buku saja dalam proses pembelajaran. Pada media Multimedia Pembelajaran ini, materi yang disajikan dilengkapi dengan contoh-contoh berupa Multimedia dan gambar yang menarik, sehingga materi akan lebih mudah dipahami oleh siswa dan langsung berisi kesimpulan dan umpan balik berupa tugas yang menyangkut materi yang terdapat dalam media Multimedia Pembelajaran ini. Selain itu melalui film dan Multimedia Pembelajaran dapat melengkapi pengalaman-pengalaman dasar dari siswa ketika mereka membaca, berdiskusi, berpraktik, dan lain-lain.

Hal ini sejalan dengan kelebihan media film atau Multimedia yang dikemukakan oleh Arsyad (2011) yaitu: (a) Film dan Multimedia dapat melengkapi pengalaman-pengalaman dasar dari siswa ketika mereka membaca, berdiskusi, berpraktik, dan lain-lain. Film merupakan pengganti alam sekitar dan bahkan dapat menunjukan objek yang secara normal tidak dapat dilihat. (b) Film dan Multimedia dapat menggambarkan suatu proses secara tepat yang dapat disaksikan secara berulang-ulang jika dipandang perlu. (c) Disamping mendorong dan meningkatkan motivasi, film dan Multimedia menanamkan sikap dan segi-segi afektif lainnya. (d) Film dan Multimedia yang mengandung nilai-nilai positif dapat mengundang pemikiran dan pembahasan dalam kelompok siswa. Bahkan, film dan Multimedia, seperti slogan yang sering didengar, dapat membawa 
dunia ke dalam kelas. (e) Film dan Multimedia dapat ditunjukkan kepada kelompok besar atau kelompok kecil, kelompok yang heterogen, maupun perorangan.

Dengan demikian, dilihat dari hasil penelitian pengembangan media pembelajaran dalam bentuk Multimedia Pembelajaran dengan model ADDIE untuk mata pelajaran IPS Kelas VII semester genap di SMP Negeri 1 Sukasada, media Multimedia Pembelajaran ini memiliki kontribusi yang cukup besar dalam meningkatkan hasil belajar siswa.

Hal ini sejalan dengan penelitian yang dilakukan Auzan (2017) yang menyatakan bahwa terdapat perbedaan yang signifikan hasil belajar IPS siswa antara sebelum dan sesudah menggunakan media Multimedia Pembelajaran mengalami peningkatan.

\section{SIMPULAN}

Adapun simpulan dari penelitian pengembangan ini adalah (1) Rancang Bangun Pengembangan Multimedia Pembelajaran Pengembangan media Multimedia Pembelajaran dalam penelitian ini menggunakan model pengembangan ADDIE (Analysis, Design, Development, Implementation, and Evaluation). Model pengembangan ADDIE yang digunakan dalam mengembangkan media Multimedia Pembelajaran dinyatakan berhasil karena tahapan-tahapan dari model ADDIE yang sistematis sehingga dapat menghasilkan media Multimedia Pembelajaran yang menarik, sesuai dengan karakteristik pengguna, dan efektif dalam meningkatkan hasil belajar siswa Kelas VII pada mata pelajaran IPS. (2) Validitas Hasil Pengembangan Media Multimedia Pembelajaran Berdasarkan hasil validasi terhadap media Multimedia Pembelajaran yang dikembangkan menurut review para ahli dan uji coba produk, yakni (a) menurut ahli isi mata pelajaran IPS produk berada pada kategori baik dengan persentase $88,89 \%$, (b) menurut ahli desain pembelajaran produk berada pada kategori baik dengan persentase 79,13\%, sehingga perlu dilakukan sedikit revisi berdasarkan masukan, saran dan komentar yang diberikan, dan (c) menurut ahli media pembelajaran produk berada pada kategori baik dengan persentase $86,67 \%$. (d) hasil uji coba perorangan produk mencapai tingkat persentase $88 \%$ dengan kategori baik, (e) hasil uji coba kelompok kecil produk mencapai tingkat persentase $86 \%$ dengan kategori baik, dan (f) hasil uji coba lapangan produk mencapai tingkat $86,67 \%$ dengan kategori baik. Berdasarkan hasil validasi tersebut maka produk yang dikembangkan layak digunakan untuk menunjang proses pembelajaran pada mata pelajaran IPS Kelas VII di SMP Negeri 1 Sukasada. (3) Efektivitas Hasil Pengembangan Media Multimedia Pembelajaran Efektivitas produk pengembangan media Multimedia pada pembelajaran di ukur dengan melakukan pretest dan posttest terhadap 28 orang siswa Kelas VII di SMP Negeri 1 Sukasada. Rata-rata nilai pretest adalah 51,07 dan rata-rata nilai posttest adalah 86,61 . Setelah dilakukan penghitungan secara manual diperoleh hasil thitung sebesar 12,72. Kemudian harga thitung dibandingkan dengan harga pada ttabel dengan $\mathrm{db}=\mathrm{n} 1+\mathrm{n} 2-2=28+$ $28-2=54$. Harga ttabel untuk db 54 dan dengan taraf signifikansi 5\% $(\alpha=0,05)$ adalah 2,004. Dengan demikian, harga $t_{\text {hitung }}$ lebih besar daripada harga $t_{\text {tabel }}$ sehingga $\mathrm{H} 0$ ditolak dan $\mathrm{H} 1$ diterima. Dilihat dari konversi hasil belajar siswa Kelas VII di SMP Negeri 1 Sukasada, nilai rata-rata posttest siswa yaitu 86,61 berada pada kualifikasi baik. Ini berarti, media Multimedia Pembelajaran tentang penerapan pesawat sederhana dalam kehidupan sehari-hari efektif dalam meningkatkan hasil belajar siswa pada mata pelajaran IPS Kelas VII di SMP Negeri 1 Sukasada tahun pelajaran 2018/2019.

\section{Daftar Pustaka}

Agung, A.A. Gede. 2012. Metodologi Penelitian Pendidikan. Singaraja: UNDIKSHA.

Arsyad, Azhar. 2011. Media Pembelajaran. Jakarta: Rajawali Pers.

Emzir. 2012. Metodelogi Penelitian Pendidikan Kuantitatif \& Kualitatif. Jakarta: Rajawali Pers.

Koyan, I W. dan AA. Gede Agung.2012. Evaluasi Program Pendidikan. Singaraja: Universitas Pendidikan Ganesha.

Mahadewi, L. P. Putrini, I Dw. Kade Tastra, dan I Km. Sudarma. 2012. Media Multimedia Pembelajaran Berbasis Kearifan Lokal. Singaraja: Universitas Pendidikan Ganesha

Auzan I. Tastra I D K. Suwatra I W. 2017. Pengembangan Multimedia Interaktif Berorientasi Pendekatan Ilmiah Pada Mata Pelajaran Pendidikan Jasmani Olahraga Dan Kesehatan Untuk Siswa Kelas Vii Tahun Pelajaran 2016/2017 Di SMP Negeri 2 Singaraja. e-Journal Edutech Universitas Pendidikan Ganesha Tegeh, I M., I Nyoman Jampel, dan Ketut Pudjawan. 2014. Model Penelitian Pengembangan. Yogyakarta: Graha Ilmu

UU No. 20 Th. 2003 tentang Sistem Pendidikan Nasional 